\title{
Critical Factors Affecting Construction Price Index: An Integrated Fuzzy Logic and Analytical Hierarchy Process*
}

\author{
Phong Thanh NGUYEN', Quyen Le Hoang Thuy To NGUYEN ${ }^{2}$
}

Received: May 24, 2020 Revised: May 31, 2020 Accepted: July 03, 2020

\begin{abstract}
Nowadays, many construction engineering and technology enterprises are evolving to find that prosperity is driven and inspired by an open economy with dynamic markets and fierce multifaceted competition. Besides brand and product uniqueness, the ability to quickly provide customers with quotes are matters of concern. Such a requirement for prompt cost estimation of construction investment projects with the use of a construction price index poses a significant challenge to contractors. This is because the nature of the construction industry is shaped by changes in domestic and foreign economic factors, socio-financial issues, and is under the influence of various micro and macro factors. This paper presents a fuzzy decision-making approach for calculating critical factors that affect the construction price index. A qualitative approach was implemented based on in-depth interviews of experts in the construction industry in Vietnam. A synthetic comparison matrix was calculated using Buckley approach. The CoA approach was applied to defuzzified the fuzzy weights of factors that affect the construction price index. The research results show that the top five critical factors affecting the construction price index in Vietnam are (1) consumer price index, (2) gross domestic product, (3) basic interest rate, (4) foreign exchange rate, and (5) total export and import.
\end{abstract}

Keywords: Analytical Hierarchy Process, Construction Enterprises, Construction Price Index, Multiple Decision Making, Fuzzy Logic

JEL Classification Code: M19, D24, O14, P22

\section{Introduction}

The construction industry plays a vital role in the national economy of Vietnam (Luong, Tran, \& Nguyen, 2018; Sy, Likhitruangsilp, Onishi, \& Nguyen, 2017; Vo, Nguyen, \& Le-Hoai, 2019). In recent years, crucial socioeconomic development indicators of construction reached a

${ }^{*}$ Acknowledgements: The author acknowledge the Ministry of Education and Training, Vietnam and Ho Chi Minh City Open University, Vietnam, for helping this research.

${ }^{1}$ First Author, Assistant Professor, Department of Project Management, Ho Chi Minh City Open University, Vietnam. Email: phong.nt@ou.edu.vn

${ }^{2}$ Corresponding Author. Assistant Professor, Deputy Director, Office of Cooperation and Research Management, Ho Chi Minh City Open University, Vietnam [Postal Address: 97, Vo Van Tan Street, Ward 6, District 3, Ho Chi Minh City, 724000, Vietnam] Email: quyen.nlhtt@ou.edu.vn

(c) Copyright: The Author(s)

This is an Open Access article distributed under the terms of the Creative Commons Attribution Non-Commercial License (http://Creativecommons.org/licenses/by-nc/4.0/) which permits unrestricted noncommercial use, distribution, and reproduction in any medium, provided the original work is properly cited. fairly high growth rate. For example, the production value of construction at 2016 prices was estimated at VND1,089.3 trillion, an increase of $10.4 \%$ from 2015. This accounted for $6.19 \%$ of the national GDP (2015: accounting for $5.97 \%$ of GDP). The national urbanization rate was about $36.6 \%$, an increase of $0.9 \%$ from 2015. It is predicted that civil engineering and industrial construction would grow at an average rate of $6.6 \%$ per year from 2017 to 2025 and that there was a bright outlook in the construction market in the coming years. The domestic economy has grown to be stable and sustainable, the pace of urbanization has improved and is expected to surge in the future (Lee \& Xuan, 2019; Nguyen $\&$ Ngoc, 2020). Amendments and supplements to Vietnam's laws and relevant legal provisions, together with stimulus policies, have heated the real-estate market, thus, driving the rise of the construction industry.

Besides, Vietnam is in a transition from a centrallyplanned economy to a socialist-oriented market economy (Nguyen, Tran, \& Huynh, 2019; To, Ha, Nguyen, \& Vo, 2019; Wrana \& Nguyen, 2019). Thus, modifications and completion of mechanisms and policies in the legal system regarding investment and construction management, as well 
as changes in material price, labor, and machinery costs, have seriously affected the construction costs (Pham, Dao, Cho, Nguyen, \& Pham-Hang, 2019; Vo et al., 2019). On the other hand, since construction projects take a long time to complete, the construction costs are subject to market fluctuations, especially financial and socio-economic factors. All these issues make construction work overtime not extremely comparable in terms of quantity and price while puzzling cost estimators limit sound estimations and effective control of costs. This challenge prompts the need to identify the construction price index of the works as well as macro-influencers. A construction price index is of paramount importance for the success of any engineering project as it helps to accurately estimate the cost of the project, prepare the budget at the initial planning, and manage and control costs throughout the life of the construction project (Cao \& Ashuri, 2020). Therefore, this paper presents critical evaluation factors that affect the construction price index using the fuzzy analytical hierarchy methodology.

\section{Literature Review}

It is a common practice worldwide that construction price indices are declared by official state authorities (Elfahham, 2019; Wang \& Ashuri, 2017). In some countries, several sources provide construction price indices, but in others, there is only one formal agency authorized by the State to quote them. The construction price indices are typically published on the website of official state agencies (for example, the Ministry of Construction or Department of Construction), newspapers and journals, or statistical yearbooks (Moon, Chi, \& Kim, 2018). The quotation may be made on a quarterly, half-year, or yearly basis.

In countries that neighbor Vietnam, as well as many other parts of the world, construction price indices are assessed by the balance of market supply and demand (Rafiei \& Adeli, 2018). These construction price indices reflect the fluctuation of construction costs over time and serve as a basis for the calculation and adjustment of total investment and management of work construction investment cost (Long, Tran, \& Nguyen, 2019; Nguyen \& Nguyen, 2020). Construction price indices are distinguished by the type of work, area, and quotation time. Also, they are expressed as the ratio of the construction cost at the time of comparison to the construction cost at the reference time. Therefore, construction price indices represent the fluctuation (increase or decrease) of work construction costs over time (Ling \& Hoang, 2010).

Correct measurement of construction price indices serves as a powerful management tool that assists construction stakeholders, allows the construction investment cost to be correctly, and fully worked out, straight on the groundwork of the project (Saar, Chuing, Yusof, Zakaria, \& Chuan,
2019; Zhang, Xing, Ye, Lu, \& Shan, 2019). Thus, further adjustment of costs during project performance is minimized and simplified while being able to catch up with market demand. In particular for:

(i) Project owners: it serves as a basis for sound measurement of the total investment amount, proper cost estimates, and pricing of bidding package during project preparation, management, and implementation.

(ii) Contractors and subcontractors: it enables the disposition of science-based construction bidding pricing strategies based on specific conditions, construction times, frame and funding schedules, etc.

(iii) Consultants: it assists in project preparation, costmanagement consultancy, and proper measurement of the total investment amount at project preparation. This provides investors with a foundation for cost management during project implementation;

(iv) Regulatory agencies, financial institutions, and banks that fund projects: it serves as a basis for management and allocation of funds and adjustment of costs during project implementation.

In Vietnam, construction price indices are published by the Department of Construction and determined for five types of construction work (civil, industrial, transport, waterworks, and technical infrastructural works). The following documents are the foundation for the calculation of the construction price index: (i) the State's documents on investment and construction management; (ii) Vietnamese construction regulations and standards; (iii) bases for the classification and grading of works according to current regulations; (iv) regimes, policies and regulations on management of construction investment costs, use of labor, supplies, construction vehicles and machinery, and other relevant costs at the time of calculation; (v) the cost base at the time of calculation; (vi) statistics on the cost structure by types of construction work; and (vii) specific data on costs of work implementation, etc.

Construction price indices are always used for evaluating changes in the labor force and construction materials. In the United Kingdom, Akintoye, Bowen, and Hardcastle (1998) found leading factors that affect construction price indices include interest rates, investment intention, new empowerment of architects, drawing production, requirements, orders, expected work volume, and construction costs. Meanwhile, Shahandashti and Ashuri (2013), from the US, proposed some factors affecting construction price indices, namely, the consumer price index, the gross domestic product, construction permits, the supply of currency, the production cost index, crude oil prices, and employment rate in the construction industry. 
In addition to the literature review, the qualitative approach was implemented based on in-depth interviews of experts in the construction industry in Vietnam. The research explored nine critical factors that affect the construction price index, as shown in figure 1.

\section{Research Methodology}

The fuzzy logic and analytical hierarchy process were conducted based on the group decision evaluation of construction experts in Vietnam. In other words, we developed all the pairwise comparison matrices based on expert input data. Three main steps are presenting the calculation process of the weights of factors affecting construction price index based on fuzzy logic and analytical hierarchy process (Nguyen, Nguyen, Nguyen, \& Huynh, 2019):

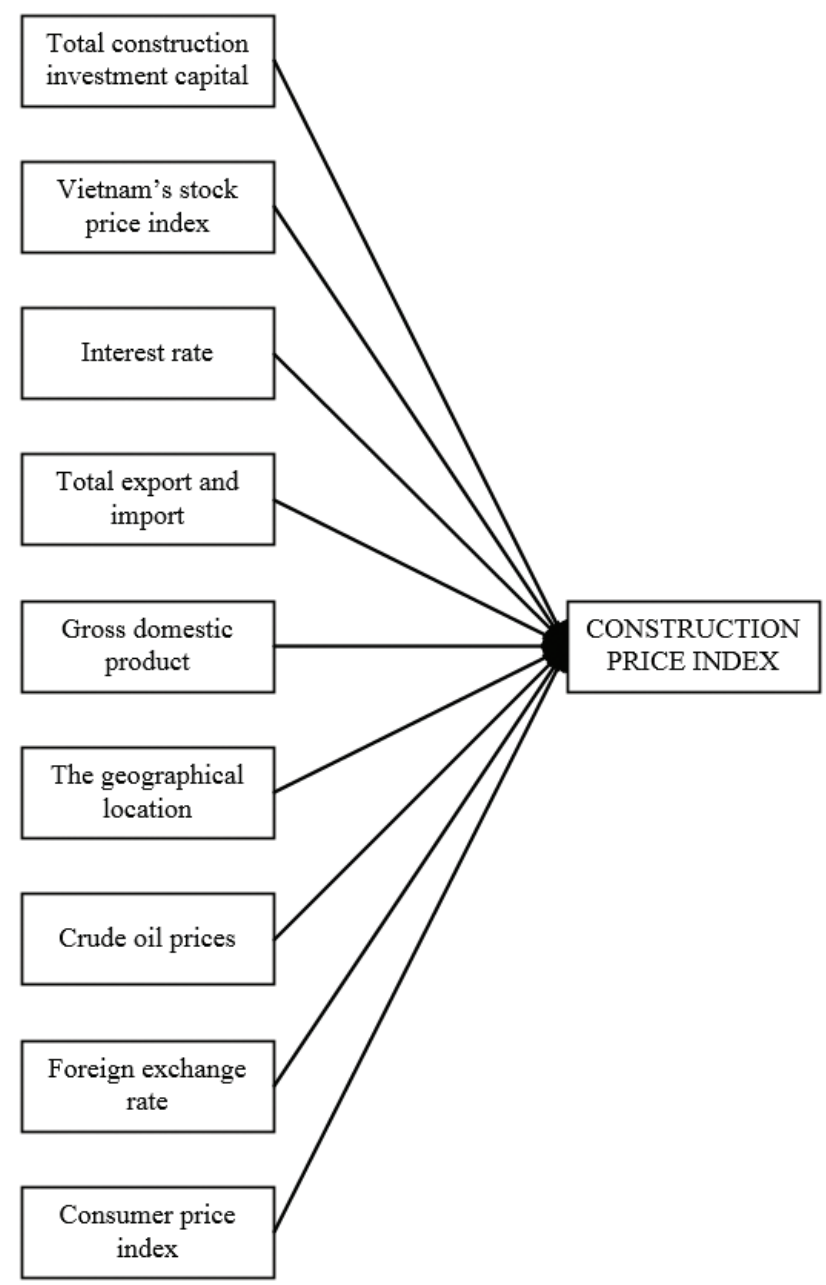

Figure 1: Critical factors affecting the construction price index in Vietnam
Step 1. We calculated the synthetic comparison matrix using Buckley approach:

$$
\tilde{b}_{i j}=\left(\tilde{b}_{i j}^{1} \otimes \tilde{b}_{i j}^{2} \otimes \tilde{b}_{i j}^{3} \otimes \ldots \otimes \tilde{b}_{i j}^{n-1} \otimes \tilde{b}_{i j}^{n}\right)
$$

Step 2. Next, we need to solve the fuzzy weights of factors affecting construction price index:

$$
\tilde{q}_{i}=\left(\tilde{b}_{i 1} \otimes \tilde{b}_{i 2} \otimes \ldots \otimes \tilde{b}_{i, n-1} \otimes \tilde{b}_{i n}\right)^{1 / n}
$$

Moreover, for the weight of any factor affecting the construction price index:

$$
\tilde{w}_{i}=\tilde{q}_{i} \otimes\left(\tilde{q}_{1} \oplus \tilde{q}_{2} \ldots \oplus \tilde{q}_{n-1} \oplus \tilde{q}_{n}\right)^{-1}
$$

where $\tilde{w}_{i}$ is indicated by a triangle number in a fuzzy environment.

Step 3. In this research, we applied the CoA approach to defuzzified the fuzzy weights of factors that affect the construction price index in Vietnam:

$$
P_{w_{i}}=\left[\left(C_{w_{i}}-A_{w_{i}}\right)+\left(B_{w_{i}}-A_{w_{i}}\right)\right] / 3+A_{w_{i}}
$$

where $P_{w_{i}}$ is the best non-fuzzy performance value.

\section{Results and Discussion}

Firstly, we can use formulas (1) and (2) to obtain the synthetic matrix and fuzzy weights of the factors affecting the construction price index:

$$
\begin{aligned}
& \tilde{q}_{1}=\left(\tilde{b}_{11} \otimes \tilde{b}_{12} \otimes \tilde{b}_{13} \ldots \otimes \tilde{b}_{17} \otimes \tilde{b}_{18} \otimes \tilde{b}_{19}\right)^{1 / 9} \\
& \tilde{q}_{1}=\left[\begin{array}{l}
(1.000 \times 0.9036 \times \ldots \times 0.3593)^{1 / 9} \\
(1.000 \times 1.1067 \times \ldots \times 0.4518)^{1 / 9} \\
(1.000 \times 1.4142 \times \ldots \times 0.6389)^{1 / 9}
\end{array}\right] \\
& \tilde{q}_{1}=(0.7373,0.9920,1.3329) .
\end{aligned}
$$

Likewise, we can obtain the remaining $\tilde{q}_{i}$ :

$$
\begin{aligned}
& \tilde{q}_{2}=(0.7071,0.9594,1.3075), \\
& \tilde{q}_{3}=(0.8118,1.1115,1.5104), \\
& \tilde{q}_{4}=(0.7311,0.9971,1.3633), \\
& \tilde{q}_{5}=(0.8275,1.1815,1.6569),
\end{aligned}
$$




$$
\begin{aligned}
& \tilde{q}_{6}=(0.5247,0.7130,0.9986), \\
& \tilde{q}_{7}=(0.6081,0.8118,1.0975), \\
& \tilde{q}_{8}=(0.8186,1.1023,1.4833), \\
& \tilde{q}_{9}=(0.9415,1.2577,1.6433),
\end{aligned}
$$

Then, the weight of each factor can be found using formula (3) as follows:

$$
\begin{aligned}
\tilde{w}_{1}=\tilde{q}_{1} \otimes\left(\tilde{q}_{1} \oplus \tilde{q}_{2} \oplus \tilde{q}_{3} \oplus \ldots \oplus \tilde{q}_{7} \oplus \tilde{q}_{8} \oplus \tilde{q}_{9}\right)^{-1} \\
=(0.7373,0.9920,1.3329) \otimes[1 /(1.3329+1.3075 \\
\quad+\ldots+1.6433), 1 /(0.9920+0.9594+\ldots+1.2577, \quad 1 / \\
\quad(0.7373+0.7071+\ldots+0.9415)] \\
\tilde{w}_{1}=(0.0595,0.1087,0.1987) .
\end{aligned}
$$

Likewise, we can obtain the weight of the remaining factors:

$$
\begin{aligned}
& \tilde{w}_{2}=(0.0571,0.1051,0.1949), \\
& \tilde{w}_{3}=(0.0655,0.1218,0.2252), \\
& \tilde{w}_{4}=(0.0590,0.1093,0.2032), \\
& \tilde{w}_{5}=(0.0668,0.1295,0.2470), \\
& \tilde{w}_{6}=(0.0423,0.0781,0.1489), \\
& \tilde{w}_{7}=(0.0491,0.0889,0.1636), \\
& \tilde{w}_{8}=(0.0660,0.1208,0.2211), \\
& \tilde{w}_{9}=(0.0760,0.1378,0.2450) .
\end{aligned}
$$

To take the P value of the fuzzy weight of the first factor as an example, the calculation process is as follows:

$$
\begin{aligned}
P_{w_{1}} & =\left[\left(C_{w_{1}}-A_{w_{1}}\right)+\left(B_{w_{1}}-A_{w_{1}}\right)\right] / 3+A_{w_{1}} \\
& =[(0.1987-0.0595)+(0.1087-0.0595)] / 3+0.0595 \\
P_{w_{1}} & =0.1223
\end{aligned}
$$

Similarly, the fuzzy weights for the remaining factors affecting the construction price index can also be found, as shown in Table 1.

The research results show that the consumer price index is the most crucial factor affecting the construction price index in Vietnam. It is a percentage value reflecting the relative deviation of consumer goods prices over time (Boskin, Dulberger, Gordon, Griliches, \& Jorgenson, 1998; Konny, 2020). It varies relatively because it is calculated for a defined group of goods that represent all consumer goods. The consumer price index is the most widely used indicator to measure prices. The fluctuation of the price is called inflation. A low inflation level favors the development of construction. Rising inflation reduces the already narrow profit margin for construction contractors, and at the same time, pushes up the interest rate, which adversely affects construction demand.

In recent years, there has been a stable inflation rate of $3-4 \%$ per year in Vietnam, about half the average of the past 20 years (Ha, Le, \& Trung-Kien, 2019; Nguyen, 2008). Nonetheless, this rate is high compared to neighboring countries and gives signs of an upsurge. This is due to the upward price adjustment of goods and services under the State's control, including electricity, health care services, education, petrol, and the environmental protection tax. etc. (Nguyen, Mai, \& Huynh, 2019). Moreover, Vietnam's economy has transcended its potential, which may raise the prices of popular goods.

Besides, the consumer price index is estimated to correlate mostly with construction price indices. This is understandable as the fluctuations of market prices directly affect the price of construction products, which drives construction price index volatility. The consumer price index affects construction price indices as it relates to construction materials, labor, and machinery, particularly:

(i) Material: the consumer price index determines whether the demand for housing and types of construction materials increases or decreases. When the need for repair and construction of houses, roads,

Table 1: The weights for factors affecting the construction price index in Vietnam

\begin{tabular}{|l|c|c|}
\hline $\begin{array}{c}\text { Factors Affecting the Construction } \\
\text { Price Index in Vietnam }\end{array}$ & Weight & Rank \\
\hline Total construction investment capital & 0.1223 & 6 \\
\hline Vietnam's stock price index & 0.1190 & 7 \\
\hline Basic interest rate & 0.1375 & 3 \\
\hline Total export and import & 0.1238 & 5 \\
\hline Gross domestic product (GDP) & 0.1477 & 2 \\
\hline $\begin{array}{l}\text { The geographical location of the } \\
\text { construction project }\end{array}$ & 0.0898 & 9 \\
\hline Crude oil prices & 0.1005 & 8 \\
\hline Foreign exchange rate & 0.1360 & 4 \\
\hline Consumer price index (CPI) & 0.1529 & 1 \\
\hline
\end{tabular}


etc., changes, the price of maintenance materials and repair services will be varied accordingly. This fluctuation partly affects the movements of the material construction price index.

(ii) Labor: the consumer price index reflects the degree of improvement or degradation of living quality. It directly influences the laborers' salaries and incomes. An upsurge in the CPI correspondingly raises the demand of the people. In such cases, the State may introduce new policies and mechanisms on salary adjustment. This then affects the quotation on the construction price indices for labor.

(iii) Construction machinery and equipment: the value of construction machinery is calculated based on the historical cost, depreciation, repair, fuel, machine operators, etc. Its influence on the costs of materials and labor tacitly affects its indirect impacts on construction machinery prices.

Gross domestic product was evaluated as the second most important critical factor affecting the construction price index in Vietnam. Gross domestic product measures the total monetary value of all goods and services produced by a country during a specified period with the use of its production elements (El-Adaway, Ali, Abotaleb, \& Barber, 2020; Lalwani \& Chakraborty, 2020). Gross domestic product gives an overall evaluation of the economic growth rate and the development level of a region or country. It is the market value of all goods and services produced within a given territory (usually a country or region) during a given period (Devaraj, Patel, \& Hicks, 2020; Mohamed Mustafa, 2019).

In Vietnam, gross domestic product is calculated by the General Statistics Office (GSO) based on reports of economic units and organizations as well as reports from provincial and centrally-run cities' statistical offices. Data on gross domestic product at current prices and gross domestic product at constant prices can be calculated based on the General Statistics Office's data. In general, the changes in gross domestic product would lead to changes in the value of raw materials and production materials in construction products. Gross domestic product per capita is the metric for the income and living standards of the people in a country. It reflects the production per capita during a specified period. High gross domestic product per capita implies high income and living standards for the people in that country, which affects the cost of labor and construction price indices.

The basic interest rate was ranked as the third most critical factor affecting the construction price index in Vietnam. It is the interest rate announced by the State Bank (da Silva \& Pirtouscheg, 2015). Contractors who require funds for production and business, pay keen attention to the fluctuation of interest rates, especially as it affects the production of construction materials, mining or provision of quarries, sand, and construction materials for projects. For instance, reliance on loan capital with fluctuating interest rates will drive the changes in the value of construction products. In some cases, if a bank's lending interest rates increase due to the scarcity of money, the construction investment may slow down or contract, and thus, lower the construction price index. The correlation between those two factors in Vietnam, however, is weakened by the economic recession, which typically rolls back the construction industry, even when banks make rate adjustments favorable to construction enterprises.

Next, the foreign exchange rate is also a major factor affecting the construction price index in Vietnam. The difference in the conversion between United States dollars (USD) and the Vietnamese Dong (VND) at different times or the ability to mobilize funds, settle debts, and invest in projects involving overseas matters is of substantial concern. A rise or fall in the USD rate affects enterprises that use United States dollars (Nguyen, Nguyen, Ngo, \& Nguyen, 2019; Qamruzzaman, Karim, \& Wei, 2019). In particular, an appreciating USD against other currencies has been and will greatly impact the VND exchange rate. Then, the domestic exchange rates will be under great pressure.

However, the State Bank of Vietnam is pursuing policies to stabilize the foreign exchange markets and exchange rates. It will act in line with executive solutions on the interest rate, deposit, and so on in the long run. The USD would likely appreciate against the VND, which places pressure on domestic exchange rates. Some experts recommend that the State Bank should reduce administrative curbs in the near term so that the VND can catch up with the market movements. For the construction sector, it is a common practice to translate the domestic currency into USD when exporting or importing construction materials (Nguyen \& Likhitruangsilp, 2017). When the USD appreciates against the VND, Vietnam's enterprises suffer devaluation in currency transactions. This affects the cost of inputs and, therefore, construction price indices.

Total export and import was ranked as the fifth most critical factor affecting the construction price index in Vietnam. Total export is the total revenue from the export of products, goods, and services nationwide during a fiscal year (budget year) (Tu \& Giang, 2018). This is an essential indicator of economic growth. The movement of total exports parallels the construction of infrastructure for production. Further, the cash inflow also contributes to and boosts the local construction industry. Total import is the total cost for the import of products, goods, and services nationwide in a fiscal year (budget year) (Gouvêa \& Schettini, 2015). The reliance of a part of the construction industry on international markets is demonstrated by its substantial imports of machinery and equipment for construction purposes. 
Total exports typically relate to whether construction materials can be produced by domestic enterprises or not. For example, most steel milling factories in Vietnam can produce only long-shape steel and common products such as round rebar, D10 - D41 deformed rebar, D6 - D10 steel rods, or medium and small-sized steel forms for construction and processing. Large and long-sized steel (larger than D41) and flat steel for big projects are not locally available and must be imported. The limited domestic production capacity against a high demand prompts a need for steel imports. Furthermore, tight control of national borders can disturb exports and thus drives the changes in construction materials price. It can be concluded that the fluctuation of import-export balance will result in the price of materials in general and construction materials in particular, thus directly impacting on construction price indices.

Total construction investment capital was ranked as the sixth critical factor affecting the construction price index in Vietnam. This indicator reflects the costs for implementation of basic construction investment projects (including new procurement of fixed assets, new construction or repair, renovation, and expansion or retooling of construction engineering) and how the settlement of basic construction investment projects progress. In other words, it refers to all costs for the achievement of the investment target, including the costs for surveys, design and construction, procurement, installation of machinery and equipment, and other expenses included in the total estimate. If the capital for a project is insufficient or not allocated on time, the investing enterprise will mobilize or advance a fund by itself. For example, a project with a short schedule requires 10 units of capital in a year, but the contractor can manage only 4 to 5 units. The contractor has to make advance payments, which creates floating debts. When a floating debt is not repaid quickly, a contract that has been accepted will be re-priced in line with the inflation level so that the contractor will not suffer damage. This does affect the construction cost index.

\section{Conclusions}

The construction price index informs us about the changes in the costs of industry sectors, which are a result of a combination of labor, materials, and equipment cost variables. It also helps contractors to identify trends, movements, and orientations in the construction market. Furthermore, it serves as a tool for determining and adjusting the total investment amount, estimating construction costs, adjusting a contract's value, settling contracts, translating investment capital, etc. Most construction and engineering investment projects take a long time to complete. Therefore, it is essential to explore the major factors affecting construction price indices. Upon consultation with knowledgeable construction experts, this study has pointed out several critical factors that affect construction price indices, including basic loan interest rates, gross domestic product, consumer price index, exchange rates, total exports and imports, Vietnam's stock index, crude oil prices, the geographical location of the construction area, etc. The research results show that all of these factors have some or little impact on the construction price indices, but that the consumer price index is the most crucial factor among them.

\section{References}

Akintoye, A., Bowen, P., \& Hardcastle, C. (1998). Macro-economic leading indicators of construction contract prices. Construction Management \& Economics, 16(2), 159-175. https://doi. org/10.1080/014461998372466

Boskin, M. J., Dulberger, E. L., Gordon, R. J., Griliches, Z., \& Jorgenson, D. W. (1998). Consumer prices, the consumer price index, and the cost of living. Journal of Economic Perspectives, 12(1), 3-26. https://doi.org/10.1257/jep.12.1.3

Cao, Y., \& Ashuri, B. (2020). Predicting the volatility of highway construction cost index using long short-term memory. Journal of Management in Engineering, 36(4). https://doi.org/10.1061/ (ASCE)ME.1943-5479.0000784

da Silva, G. J. C., \& Pirtouscheg, L. A. S. (2015). Basic interest rate, bank competition and bank spread in personal credit operations in brazil: A theoretical and empirical analysis. EconomiA, 16(1), 32-45. https://doi.org/10.1016/j.econ.2014.12.001

Devaraj, S., Patel, P. C., \& Hicks, M. J. (2020). Must access laws for opioid prescription and county gross domestic product: Evidence from the us. Applied Economics Letters. https://doi. org/10.1080/13504851.2020.1740155

El-Adaway, I. H., Ali, G. G., Abotaleb, I. S., \& Barber, H. M. (2020). Studying the relationship between stock prices of publicly traded us construction companies and gross domestic product: Preliminary step toward construction-economy nexus. Journal of Construction Engineering and Management, 146(1). https://doi.org/10.1061/(ASCE)CO.1943-7862.0001742

Elfahham, Y. (2019). Estimation and prediction of construction cost index using neural networks, time series, and regression. Alexandria Engineering Journal. doi:https://doi.org/10.1016/j. aej.2019.05.002

Gouvêa, R. R., \& Schettini, B. P. (2015). Empirical estimates for the brazilian total imports equation using quarterly national accounts data (1996-2010). EconomiA, 16(2), 250-271. https:// doi.org/10.1016/j.econ.2015.06.001

Ha, N. M., Le, N. D., \& Trung-Kien, P. (2019). The impact of urbanization on income inequality: A study in vietnam. Journal of Risk and Financial Management, 12(3), 14. https://doi. org/10.3390/jrfm12030146

Konny, C. (2020). Modernizing data collection for the consumer price index. Business Economics, 55(1), 45-52. https://doi. org/10.1057/s11369-019-00146-3 
Lalwani, V., \& Chakraborty, M. (2020). Aggregate earnings and gross domestic product: International evidence. Applied Economics, 52(1), 68-84. https://doi.org/10.1080/00036846.2 019.1640859

Lee, J. W., \& Xuan, Y. (2019). Effects of technology and innovation management and total factor productivity on the economic growth of china. Journal of Asian Finance, Economics and Business, 6(2), 63-73. https://doi.org/10.13106/jafeb.2019. vol6.no2.63

Ling, F. Y. Y., \& Hoang, V. T. P. (2010). Political, economic, and legal risks faced in international projects: Case study of vietnam. Journal of Professional Issues in Engineering Education and Practice, 136(3), 156-164. https://doi.org/10.1061/(ASCE) EI.1943-5541.0000015

Long, L. D., Tran, D. H., \& Nguyen, P. T. (2019). Hybrid multiple objective evolutionary algorithms for optimising multi-mode time, cost and risk trade-off problem. International Journal of Computer Applications in Technology, 60(3), 203-214. https:// doi.org/10.1504/IJCAT.2019.100299

Luong, D. L., Tran, D. H., \& Nguyen, P. T. (2018). Optimizing multi-mode time-cost-quality trade-off of construction project using opposition multiple objective difference evolution. International Journal of Construction Management, 01-13. https://doi.org/10.1080/15623599.2018.1526630

Mohamed Mustafa, A. M. (2019). Contribution of tourism and foreign direct investment to gross domestic product: Econometric analysis in the case of sri lanka. Journal of Asian Finance, Economics and Business, 6(4), 109-114. https://doi. org/10.13106/jafeb.2019.vol6.no4.109

Moon, S., Chi, S., \& Kim, D. Y. (2018). Predicting construction cost index using the autoregressive fractionally integrated moving average model. Journal of Management in Engineering, 34(2), 04017063. https://doi.org/10.1061/(ASCE)ME.19435479.0000571

Nguyen, H. M., Mai, L. T., \& Huynh, T. L. (2019). The role of transformational leadership toward work performance through intrinsic motivation: A study in the pharmaceutical field in vietnam. Journal of Asian Finance, Economics and Business, 6(4), 201-212. https://doi.org/10.13106/jafeb.2019.vol6. no4.201

Nguyen, H. M., \& Ngoc, B. H. (2020). Energy consumption economic growth nexus in vietnam: An ardl approach with a structural break. Journal of Asian Finance, Economics and Business, 7(1), 101-110. https://doi.org/10.13106/jafeb.2020. vol7.no1.101

Nguyen, H. M., Nguyen, C., Ngo, T. T., \& Nguyen, L. V. (2019). The effects of job crafting on work engagement and work performance: A study of vietnamese commercial banks. Journal of Asian Finance, Economics and Business, 6(2), 189-201. https://doi.org/10.13106/jafeb.2019.vol6.no2.189

Nguyen, K. Q. (2008). Impacts of a rise in electricity tariff on prices of other products in vietnam. Energy Policy, 36(8), 3145-3149. https://doi.org/10.1016/j.enpol.2008.04.013
Nguyen, M. H., Tran, B. T., \& Huynh, L. T. (2019). Relation between employees and customers affects to the positive word of mouth through customer satisfaction. Journal of Distribution Science, 17(6), 65-75. https://doi.org/10.15722/JDS.17.6.201906.65

Nguyen, P., \& Nguyen, P. (2020). Risk management in engineering and construction: A case study in design-build projects in vietnam. Engineering, Technology \& Applied Science Research, 10(1), 5237-5241.

Nguyen, P. T., \& Likhitruangsilp, V. (2017). Identification risk factors affecting concession period length for public-private partnership infrastructure projects. International Journal of Civil Engineering and Technology, 8(6), 342-348.

Nguyen, P. V., Nguyen, P. T., Nguyen, Q. L. H. T. T., \& Huynh, V. D. B. (2019). Extended fuzzy analytical hierarchy process approach in determinants of employees' competencies in the fourth industrial revolution. International Journal of Advanced Computer Science and Applications, 10(4), 150-154. https:// doi.org/10.14569/IJACSA.2019.0100417

Pham, H. C., Dao, N. N., Cho, S., Nguyen, P. T., \& Pham-Hang, A. T. (2019). Construction hazard investigation leveraging object anatomization on an augmented photoreality platform. Applied Sciences (Switzerland), 9(21). https://doi.org/10.3390/ app9214477

Qamruzzaman, M., Karim, S., \& Wei, J. (2019). Does asymmetric relation exist between exchange rate and foreign direct investment in bangladesh? Evidence from nonlinear ardl analysis. Journal of Asian Finance, Economics and Business, 6(4), 115-128. https://doi.org/10.13106/jafeb.2019.vol6. no4.115

Rafiei, M. H., \& Adeli, H. (2018). Novel machine-learning model for estimating construction costs considering economic variables and indexes. Journal of Construction Engineering and Management, 144(12), 04018106. https://doi.org/10.1061/ (ASCE)CO.1943-7862.0001570

Saar, C. C., Chuing, L. S., Yusof, A. M., Zakaria, R., \& Chuan, T. M. (2019). Construction cost index: A case study in malaysia. Paper presented at the IOP Conference Series: Materials Science and Engineering.

Shahandashti, S., \& Ashuri, B. (2013). Forecasting engineering news-record construction cost index using multivariate time series models. Journal of Construction Engineering and Management, 139(9), 1237-1243. https://doi.org/10.1061/ (ASCE)CO.1943-7862.0000689

Sy, D. T., Likhitruangsilp, V., Onishi, M., \& Nguyen, P. T. (2017). Different perceptions of concern factors for strategic investment of the private sector in public-private partnership transportation projects. ASEAN Engineering Journal, 7(2), 66-86.

To, A. H., Ha, D. T. T., Nguyen, H. M., \& Vo, D. H. (2019). The impact of foreign direct investment on environment degradation: Evidence from emerging markets in asia. International Journal of Environmental Research and Public Health, 16(9). https:// doi.org/10.3390/ijerph16091636 
Tu, M. T. C., \& Giang, H. T. T. (2018). Estimating the impact of trade cost on export: A case study vietnam. Journal of Asian Finance, Economics and Business, 5(3), 43-50. https://doi. org/10.13106/jafeb.2018.vol5.no3.43

Vo, K. D., Nguyen, P. T., \& Le-Hoai, L. (2019). The difference in personality traits of construction engineers in vietnam using the kts instrument. Suranaree Journal of Science and Technology, 26(2), 232-239.

Wang, J., \& Ashuri, B. (2017). Predicting enr construction cost index using machine-learning algorithms. International
Journal of Construction Education and Research, 13(1), 47-63. https://doi.org/10.1080/15578771.2016.1235063

Wrana, J., \& Nguyen, T. X. T. (2019). 'Strategic coupling' and regional development in a transition economy: What can we learn from vietnam? Area Development and Policy, 4(4), 455466. https://doi.org/10.1080/23792949.2019.1608838

Zhang, R., Xing, J., Ye, K., Lu, W., \& Shan, Y. (2019). Synchronicity of global construction cost indexes. Engineering, Construction and Architectural Management, 26(3), 367-385. https://doi. org/10.1108/ECAM-02-2018-0045 